\title{
ИЗ ИСТОРИИ РАЗВИТИЯ ОБРАЗОВАНИЯ НА ДОНУ (XIX НАЧАЛЕ XX ВВ.)
}

\section{FROM THE HISTORY OF EDUCATION ON THE DON (XIX-XX CENTURIES)}

V. Lobova

Summary: The development of education on the don went from individual schools of literacy, which appeared in the middle of the XVIII century, to higher education institutions in the early twentieth century. Primary schools and colleges were predominant, where only basic knowledge was given. At the end of the XIX - beginning of the XX century, the formation of the don education system was completed. The number of high schools and real schools increased; a network of commercial schools was created; the first higher education institutions appeared on the don (Novocherkassk Polytechnic and teachers ' Institute, as well as the Warsaw University transferred to Rostov-on-don).

Keywords: school, gymnasium, College, education, reforms, science, library, don education.
$\mathrm{Y}$ ровень образования широких слоев населения, является одним из ключевых показателей культурного развития государства в целом, и его отдельных регионов в частности.

Осмысление особенностей развития образования на Дону XIX начале XX вв., а также понимание его сущностных характеристик, приобретает особую актуальность в современных условиях, в свете обусловленной необходимости повышения роли школьного, средне-специального и университетского образования, в связи с происходящими процессами его модернизации.

B XIX - начале XX веков шел активный процесс становления и развития системы народного просвещения, как в России, так и в Донском регионе.

Сложившаяся к концу XVIII века система образования в России, не могла обеспечить страну необходимым количеством образованных людей, которые требовались в условиях развивающихся промышленности и торговли. В 1800 году в России существовало 549 Главных и Малых народных училищ, пансионов и школ с 61960 учащимися. Кроме них было еще 4 духовные академии, 35 семинарий и 76 низших архиерейских школ. Все они были расположены исключительно в городах, и, прежде всего, в Санкт-Петербурге и Москве [16, с. 137].

Для руководства системой образования в 1802 году было учреждено Министерство народного просвеще-
Лобова Виктория Владимировна

К.и.н., дочент, Южный Федеральный Университет,

2. Ростов-на Дону

0101023@list.ru

Аннотация: Развитие образования на Дону прошло путь от единичных школ грамоты, появившихся в середине XVIII века, до высших учебных заведений в начале XX века. Преобладающими были начальные школы и училища, в которых давались лишь элементарные знания. B конце XIX - начале XX века был завершён процесс формирования на Дону системы образования. Увеличилось число гимназий и реальных училищ; была создана сеть коммерческих училищ; на Дону появились первые высшие учебные заведения (Новочеркасский политехнический и учительский институт, а также переведенный в Ростов-на-Дону Варшавский университет).

Ключевые слова: школа, гимназия, училище, образование, реформы, наука, библиотека, Донское просвещение.

ния. 24 января (8 февраля) 1803 г. было утверждено Положение об устройстве учебных заведений. В результате, в стране было организовано шесть учебных округов, во главе которых стояли попечители. В 1804 г. был утвержден «Устав учебных заведений, подведомых университетам», который вводил четыре типа учебных заведений, преемственно связанных между собой: приходские и уездные училища, гимназии (по одной в каждой губернии) и университеты [13].

Цель реформы образования состояла в создании единой, взаимосвязанной во всех звеньях, системы: приходские училища должны были готовить к поступлению в уездные, уездные - в гимназии, гимназии - в университеты. Однако этого не удалось достичь. Устав свёл школьное дело в селах к участию в нём духовенства без конкретного материального обеспечения, но с прибавкой административной регламентации со стороны министерства, попечителей округов и т.д. Видя в университетах решающее звено постановки образования в России, правительство, по существу, игнорировало другие звенья в системе народного образования. Получался разрыв в этой, на первый взгляд, стройной, базирующейся на строгой последовательности отдельных звеньев, системы [16].

Реформы, проводившиеся в начале XIX века в империи, естественно, затронули и систему образования на Дону. Экономическое и культурное развитие Дона требовало значительно большего количества образован- 
ных людей, чем располагал этот регион. По сведениям донских историков, до середины XVIII века на Дону не было постоянных учебных заведений. Долгое время считалось, что грамота казаку не нужна, главное, чтобы он «умел владеть шашкой и пикой».

14 августа 1746 году в столице Войска Донского Черкасске указом императрицы Елизаветы Петровны была открыта так называемая, «войсковая латинская семинария», в которой учились дети казаков и священников, готовящих к духовному званию [15, с. 171].

В крепости Св. Дмитрия, вскоре после её основания в 1761 году, была открыта школа для обучения солдатских детей. Крепостной учительский персонал был составлен из унтер-офицеров и дьяконов, учивших чтению, письму, счету и Закону Божьему. В школах обучались и обитатели близлежащих поселений, на месте которых был построен г. Ростов-на-Дону [6, с.86].

В 1767 году в Черкасске начала действовать Духовная семинария для приготовления кандидатов священства [1, с. 122]. Через 10 лет она была закрыта, так как донское духовенство перестало давать средства на её содержание. Самим фактом своего существования духовная семинария подготовила почву для развития сети войсковых светских училищ.

В «Исторической записке о Донском Главном народном и других училищах» говорится, что «от основания училища до 1 января 1795 г. перебыло в оном учеников 289. В течение минувшего 1794 г. всех налицо было 115, в 1 - 42, во 2 - 30, в 3 - 25, в 4 - 18. Из тех учеников, прошедших испытание, в 1 классе оказалось - 15, которые и переведены во 2-ой, а из 2-го - из 30 (только 18), из 3 в 4 1- человек, и 4-го выпущены с аттестатами только 4» [7, с. 222.] Первым директором Главного народного училища был П.А. Иловайский.

На Дону с начала XIX века начали открываться Малые народные училища, которые в Центральной России создавались с 1780-х годов. В 1802 году такое училище было открыто в станице Нижне-Чирской; в 1803 году в станице Усть-Медведицкой [3, с. 221].

Как было отмечено, когда начали проводиться реформы в сфере образования, территория Российской империи делилась на несколько учебных округов. Земля Войска Донского была включена в состав Харьковского учебного округа, куда также вошли: Орловская, Воронежская, Курская, Черниговская, Полтавская, Николаевская, Таврическая и Екатеринославская губернии. Попечителем учебного округа стал сенатор граф С. Потоцкий. При Харьковском университете, открытом в 1805 году, был сформирован училищный комитет, ведавший учебными заведениями на территории округа. Курировал учебные заведения Земли Войска Донского, так назы- ваемый «визитатор», которым был назначен профессор Харьковского университете И. Тимковский [3, с. 221].

Реформа образования привела к изменению статуса Главных народных училищ. Они были преобразованы в гимназии. Первой гимназией на Дону была Черкасская. В мае 1805 года из Харькова в Черкасск прибыл профессор И.Ф. Тимковский, задачей которого было создание здесь гимназии. При поддержке войскового атамана М.И. Платова 11 (23) июля 1805 года Черкасское Главное народное училище получило статус гимназии. В 1805 году в нём обучалось 253 человека.

Первым директором гимназии стал Алексей Григорьевич Попов (1763-1844 гг.). Из документов известно, что он был одним из первых донцов с университетским образованием. 4 декабря 1801 года, по распоряжению М.И. Платова, он занял должность директора учебных заведений в войске Донском, в которой он пребывал до 1 января 1824 года. Одновременно он возглавлял Главное народное училище, а затем, после реорганизации в 1805 году, Новочеркасскую гимназию. За усердие в этой деятельности, коллежскому советнику Попову в 1807 году был дан орден Св. Владимира 4-й степени.

1 сентября 1806 года в Таганроге, тогда уездном городе Екатеринославской губернии, открылась мужская гимназия с двумя низшими отделениями при ней - приходским и уездным училищами. Она называлась Коммерческой, хотя, по словам П.П. Филевского, автора книги «История города Таганрога» - таковой никогда не была $[14$, c.30].

В «Краткой исторической записки о Таганрогской гимназии», составленной её директором Э. Рейтлингером в 1880 году, приводятся цифры о количестве учеников с 1806 по 1874 годах. Судя по ним, в год открытия, в гимназию было принято 126 учеников. В последующие годы это число менялось - от 75 в 1815 году, до 179 в 1830 году. В гимназии преподавались: риторика, эстетика, греческий язык, всеобщая грамматика, психология, логика, нравственная философия, математика, физика и технология. С 1822 года была введена латынь. В приходском училище обучение традиционно сводилось к изучению Закона Божьего, чтения письма, начал арифметики. В уездном училище, кроме Закона Божьего - русская грамматика, всеобщая и русская история, география, геометрия, физика, чистописание и рисование.

Несмотря на то, что реформы на Дону привели к становлению начальной и средней школы, учебных заведений здесь было явно не достаточно. По официальным сведениям, в гимназии, уездных и приходских училищах в начале XIX века обучалось всего 462 учащихся [4, C. 234].

Проводившаяся при Николае I политика в сфере об- 
разования не могла не затронуть и учебные заведения Дона. Здесь продолжалось создание приходских и уездных училищ. Так, в 1827 году, в Ростове было открыто уездное училище [6, с. 87]. В качестве низшего отделения при нём действовало приходское училище.

Об уездных училищах Дона можно судить по «отчёту директора Хопёрского уездного училища», находившегося в ведении Войсковой администрации. Училище было открыто 29 апреля 1806 года как Малое приходское. 17 июня 1812 года оно было преобразовано в уездное училище. Отчёт - анкета содержит сведения за время с 1 января 1835 года по 1 января 1836 года. Из него следует, что в ведении уездного училища находились Хопёрское уездное и Михайловское приходское училища. Штатных преподавателей было 4. Также был один смотритель. В разделе «Часть учебная» указывалось, что в училище изучались все предметы в соответствии с Указом 1828 года. Сверх этого перечня преподавали ещё «Арифметику на счётах». Преподавание велось по учебникам, «назначенным правлением училищ». В 1835-1836 годах выбыло из училища 27 учеников. В том числе, 25 - по окончании курса обучения, 2 - до окончания «по воле родителей». Все учащиеся принадлежали к казачьему сословию. Вновь было принято 37 человек, из которых 12 принадлежали к дворянству, а 24 - к казачеству. Число учащихся к общему числу жителей в станицах Хопёрской и Михайловской (17137) составляло 102, то есть 1:168.

Училище помещалось в «войсковых двух деревянных домах не требующих починки, дом принадлежит училищу». Хопёрское уездное училище находилось «на иждивении войсковом», а Михайловское приходское содержалось «на станичные средства» [1, с. 231-232].

По сути, в таком же, либо худшем положении находилось большинство приходских и уездных училищ до середины 1850-х годов. Так, в Ведомости о Старочеркасском приходском училище за 1851 г., указано, что оно состоит из одного класса. Преподавание ведут 2 учителя. Училище помещается в «одноэтажном деревянном доме, нанимаемом за счёт войсковых сумм». Библиотека располагает 451 томом книг 228 названий. В училище в 1851 году обучалось 60 человек мужского пола. Из них: обер-офицерских детей - 2, детей из духовного сословия - 2, из урядников и казаков - 50, из купечества - 2, из крестьян - 4. Всего жителей станицы в 1851 году насчитывалось 5397 человек [2 с. 126]. Число обучавшихся в приходском училище мальчиков, было невелико.

Устав гимназий и училищ, принятый в декабре 1828 года, на Дону начал претворяться в жизнь в 1836 году. Он касался Новочеркасской гимназии, которая в течение долгого времени была единственной в Войске Донском.

Таким образом, в первой половине XIX века на Дону продолжался процесс становления начального и сред- него образования, начавшийся в середине XVIII века. Реформы, проводимые Александром I, а затем Николаем I, в полной мере касались и Дона, хотя здесь были свои особенности.

Значительные изменения в социально-экономической, общественной и культурной жизни России начали происходить после того, как в феврале 1855 года на престол вступил Александр II. Не случайно время его правления вошло в историю как «Эпоха Великих реформ». Отмена крепостного права, произошедшая в 1861 году, сделала неизбежным реформирование разных сторон жизни империи, в том числе, и её образовательной системы.

Александр II начал править страной, уровень образования населения которой не соответствовал замыслам предстоящих преобразований. Россия, вступавшая в эпоху реформ, остро нуждалась в значительном увеличении числа образованных людей.

Перемены в системе народного просвещения начались после 1855 года с отмены ограничений, введённых в последние годы правления Николая І. По распоряжению министра народного просвещения А.С. Норова (1853-1858 гг.), 2 мая 1856 года было создано Главное правление училищ. В его функцию входил контроль за деятельностью учебных заведений. Там же находился Учёный комитет, членам которого было поручено разработать проекты нового устройства начальных училищ и гимназий.

Одновременно с центральной частью страны, в начале 1860-х годов в казачьих станицах Дона начали открываться женские училища. С 1860 года в Новочеркасске функционировало женское училище первого разряда, которое готовило учительниц для станичных женских училищ. В апреле 1862 года было принято «Положение о женских училищах в станицах Войска Донского». Целью их было «распространение между казачьим сословием Войска Донского религиозно-нравственного образования, которого должно требовать от каждой женщины, в особенности же от будущей матери семейства. В круг этого образования, как необходимое условие, входит грамотность и потом первоначальное, более или менее для каждого сословия нужные знания» [9, с.79].

В станицах Дона женские училища могли быть второго или третьего разрядов. Курс обучения в них был трёхлетний, но объём учебных программ был разный. В училищах третьего разряда изучался Закон Божий, а также давались самые элементарные сведения по русскому языку и арифметике; в училищах второго разряда, наряду с этими предметами, изучались также русская история и география. Главное внимание уделялось рукоделию и женским ремёслам. Возглавляла училище надзирательница. На Дону устраивались, в основном, учи- 
лища третьего разряда.

Училища содержались на средства тех станиц, где они учреждались. В случае недостатка средств на содержание училищ Войско могло выделить дополнительные средства из войсковых сумм. В 1862-1866 годах было открыто 4 училища второго разряда и 9 училищ третьего разряда $[9$, с.80].

В конце 1861 года Александр II назначил министром народного просвещения А.В. Головнина. Впервые к управлению сферой просвещения пришёл представитель нового поколения государственных деятелей, обладавший ясными и чёткими представлениями о направлении и характере грядущих преобразований. Благодаря его деятельности, в начале 1860-х годов были разработаны документы, в соответствии с которыми были проведены реформы начальной, средней и высшей школ.

14 июня 1864 года Александр II подписал «Положение о начальных народных училищах», которое определило новый этап в развитии начального образования в России. Документ законодательно закрепил создание бессословных начальных народных школ, в которых могли обучаться «дети всех состояний... обоего пола» [12].

Кроме приходских училищ на Дону открывались начальные школы в частных и общественных домах. Это делалось не всегда с разрешения Войскового присутствия по крестьянским делам, как требовалось законом. Так, в хуторе Алитубы в 1865 году без разрешения начальства открыл школу сотник Иван Горелов. В ней обучалось 8 мальчиков. Во многих станицах школы не действовали, поскольку для них не находилось помещения. В частности, в станице Мелиховской «не было Войскового дома для помещения училища, и ни один хозяин не соглашался отдать свой дом под училище» [10, с. 67]. Такое же положение было и в других станицах.

После убийства Александра II 1 марта 1881 года и вступления на престол Александра III произошли значительные изменения во внутренней политике, коснувшиеся, естественно, и сферу народного просвещения. Консервативный курс правительства реализовывался министром народного просвещения И.Д. Деляновым. Одним из направлений его деятельности, при поддержке обер-прокурора Синода К.П. Победоносцева, было повсеместное насаждение церковно-приходских школ и увеличение средств на их содержание.

В 1887 году в состав Области войска Донского были включены Ростов, Ростовский уезд и Таганрогское градоначальство. Все они обладали значительным образовательным потенциалом. Это значительно расширило образовательное пространство донского региона, улучшив его количественные и качественные характеристики.
В Области войска Донского в 1880-х - начале 1890-х годов девствовало 527 окружных, городских и народных училищ, 759 церковно-приходских мужских и женских школ. В Новочеркасске действовали также духовная семинария и духовное училище. В Ростове толчок развитию начальных училищ был дан в период управлению городом А.М. Байкова. В 1884 году в Ростове было 10 начальных школ (7 мужских и 3 женских), в которых обучалось 629 мальчиков и девочек. В 1885 году были открыты начальные училища на Богатом Источнике и в Новом поселении. К концу 1880-х годов число учащихся в начальных училищах Ростова-на-Дону составляло уже 1216 человек (765 лиц мужского пола и 451 - женского пола). Заметно возросли расходы Ростовской городской Думы, направленные на развитие народного образования (с 20743 руб. в 1884 г. до 30995 в 1886 г.) [11, с. 230].

Политика министра народного просвещения Делянова по отношению к средней школе состояла в ограничении в гимназиях и прогимназиях числа детей из низших слоев населения. Распоряжение министра от 5 июня 1887 года, известное как «циркуляр о кухаркиных детях», предлагало принимать в гимназии и прогимназии «только таких детей, которые находятся на попечении лиц, представляющих достаточное ручательство в правильном над ними домашнем надзоре, и в предоставлении им необходимого для учебных занятий удобства».

В отличие от общероссийских учебных заведений, на Дону «обратили внимание на развитие учебных заведений, соответствующих прямым потребностям казачества». В 1883 году в столице Дона открылся Донской кадетский корпус «для подготовки детей офицеров Войска Донского к военной службе». Он был основан указом императора Александра III и с 1989 года носил имя своего основателя. На первый курс приняли 60 кадетов. Корпус имел собственное здание с церковью Донской Божьей Матери. К 1914 году в Российской империи насчитывалось 123745 начальных учебных заведений. Охват начальной школой детей в возрасте от 8 до 11 лет в 1914 году составлял в целом по Российской империи $30,1 \%$ (в городах - 46,6 \%, в сельской местности - 28,3\%).

Темпы роста учебных заведений в стране коснулись и Дона. Наиболее массовым видом образования здесь, в начале $\mathrm{XX}$ века, как и ранее, являлось начальное образование. Рост начальных учебных заведений наблюдался на протяжении всего изучаемого периода. Так, в 1893 году насчитывалось 209 приходских училищ, в 1913 году их было уже 770; соответственно число сельских училищ возросло со 163 до 369 [5, с. 262].

Эти цифры наглядно свидетельствуют о том, что казачье население Дона, с точки зрения обеспеченности начальными учебными заведениями, находилось в лучшем положении, чем крестьянское. 
Таким образом, реформы в сфере народного просвещения, проводимые в России начала 1860-х - конца 1890-х годов, благотворно отразились на развитии просвещения и на Дону. Это проявилось в заметном увеличении числа начальных и средних учебных заведений и числа учащихся в них. Несмотря на сложности в общественно-политической жизни страны, в начале XX века на Дону возросло число учебных заведений разных уровней.

Важным этапом в развитии образования южного региона, явилось создание Новочеркасского политехнического института и перевод в Ростов-на-Дону в годы Первой мировой войны Варшавского университета.

По уровню грамотности Область войска Донского занимала в начале XX века одно из первых мест в Российской империи.

В результате реформ 1860-х годов возросло число начальных учебных заведений, представленных приходскими и сельскими училищами. В 1860-х - 1880-х годах шло становление среднего образования. На Дону появились первые гимназии. Среднее образование на Дону развивалось гораздо более медленными темпами, чем начальное и было представлено также специальными военными заведениями для казаков.

Отличительной чертой Области войска Донского, естественно, как казачьей территории, было участие самого Войска, особенно в пореформенное время, в фи- нансировании образования войскового населения из имеющегося войскового бюджета.

Донское просвещение того временного периода, по сути своей, носило сословный (казачий) характер, который окончательно оформился в пореформенный период. Приоритет казачьего населения в сфере просвещения по сравнению с крестьянским населением края, был более чем очевиден. Войсковое население было на порядок лучше обеспечено учебными заведениями, и конечно в первую очередь начальными.

Но, несмотря на все имеющиеся положительные аспекты, только третья часть донских детей, школьного возраста, могла приобщиться к учебному процессу и получить образование. Обучение в регионе носило дифференцированный характер по половому признаку с учётом социальных ролей мужчин и женщин и их места в обществе. Женское образование на Дону развивалось медленно, высшие женские курсы были созданы намного позже, чем в центральной России.

Хотя темпы развития донского образования на протяжении рассматриваемого периода были очевидны, острейшими проблемами оставались слабая материальная база, отсутствие возможности получить образование для многих слоёв, а на фоне всего и постоянный дефицит квалифицированных педагогических кадров, который напрямую влиял на качество образования и рост учебных заведений в целом.

\section{ЛИТЕРАТУРА}

1. Астапенко, М.П., Астапенко Е.М. История Дона и донского казачества. Ростов н/Д. 2007.

2. Артинский, И. Очерк истории Новочеркасской гимназии. Новочеркасск. 1907.

3. История казачества России. Ростов н/Д. 1998. Т. 2.

4. История Дона. Эпоха капитализма. Ростов н/Д. 1974.

5. История Донского края XVII-XIX вв. Ростов н/Д. 2010.

6. Ильин А.М. История города Ростова-на-Дону. Ростов н/Д. 1909.

7. Кириллов, А.А. Из истории народного просвещения на Дону // Сборник 8. Областного Войска Донского Статистического комитета. Новочеркасск. 19031905. Вып. 8.

8. Кислицына, И.Г. Донское просвещение. История. События. Люди. (середина XVI - 20-е гг. XX века). Ростов н/Д. 2010.

9. Культура Донского края: Страницы истории: Сборник научных трудов. Ростов н/Д. 1996.

10. Казачий Дон: Очерки истории: в 2-х ч. / А.П. Скорик, Р.Г. Тикиджьян и др. Ростов н/Д. 1995.

11. Положение о начальных народных училищах. Полное собрание законов Российской империи. СПб. 1876. Т. 3. С. 1342-1350. htpp://www.history.ru

12. Устав учебных заведений, подведомых университетам. http://pedagogic.ru//books.

13. Филевский, П.П. История города Таганрога. 1906

14. Шумов, В.В. История казачества в вопросах и ответах. Ростов н/Д. 2004.

15. Эймонтова, Р.Г. Просвещение в первой половине XIX века. //Вопросы истории. 1986. № 10. 